線維化薬の効果的な使用法やバイオマーカーの 確立，長期使用における有害事象対策にある. 本講演では, 現在開発中の新規抗線維化薬の話
題も含め, 抗線維化薬時代を迎えた間質性肺炎/ 肺線維症の診断と治療について概説する.

\title{
7. 不整脈治療の最前線
}

\section{杏林大学医学部付属病院循環器内科副島 京子}

不整脈は“薬物療法によるコントロール”か ら“根治できるもの”に変容してきている．三 次元マッピングシステムの進歩により，心蔵の 正確な解剖学的情報と電気的特性をカラー表示 することで, 正常と異常心筋の区別, 重要部位 のタグ付け等で治療をガイドすることができる. 治療用カテーテルは，オペレータの“手の感覚” による接触力の推測から, 安全且つ有効に治療 を行えるように接触力と接触方向が表示される ようになった. 三次元マッピングの進歩と共に, 不整脈のさまざまな機序や解剖学的情報が明ら かとなり, 治療できる不整脈の種類も急増して いる，心房細動では，発作性に加えて持続性， さらには長期持続性のものも治療されるように なった。 また，基質的心疾患に合併した心室頻 拍では, 経皮的心外膜アプローチによる心外膜 アブレーション, 心筋深部のエタノールアブレー ション等が考案され, ICD (implantable cardioverter defibrillator)の頻回作動を抑えるよう
な治療が可能となった。 心房細動では, より迅 速且つ確実に肺静脈隔離を行うことが可能なバ ルーン技術が広まった. カテーテルアブレーショ ンで一般的に使用される高周波に加えて, レー ザー, 冷凍凝固等のエネルギーを用いたバルー ンシステムが用いられる。

徐脈治療では, VVIのリードレスペースメーカ が開発され，これまで必要であった前胸部の皮 下ポケット,リードが不要になり, 透析や感染 を繰り返している患者において，感染のリスク を最小限に抑えることが可能となった．患者は リードを意識せずに生活することが可能となり， 生活の質は格段に向上した。今後, さらにdual chamberへの進歩が望まれる.

このように，不整脈領域では，急速に治療の 進歩があり，知識をアップデートして少しでも 多くの患者が最新の治療の恩恵にあずかれるよ うにする必要がある。本講演では, 最新の不整 脈治療に関して話したいと思う。

\section{8. これからの糖尿病診療}

\section{国立国際医療研究センター研究所糖尿病研究センター 植木浩二郎}

この 20 年間の薬物療法の進歩もあり, 糖尿病 の血管合併症の発症率は大幅に減少している. また, 我々の行った大規模臨床試験J-DOIT3(Japan Diabetes Optimal Integrated Treatment study for 3 major risk factors of cardiovascular diseases)の結果から, 現在のガイドラインの管 理目標よりもさらに厳格なコントロールを行う ことで，より合併症を減少させることができる ことも明らかとなった。これには, インクレチ ン関連薬等の低血糖のリスクの少ない糖尿病治 
療薬の普及も大いに貢献している。 また, 特定 健診や特定保健指導の効果もあり, 糖尿病の予 備群はこの 10 年で大きく減少し, さらに, 糖尿 病の有病者数も患者の長寿化もあって頭打ちと なっている。従って, 現在, 全国的に展開され ている糖尿病性腎症の重症化予防も含めて, 糖 尿病の早期発見と早期介入が行われれば，合併 症の発症・進展を相当程度に抑制できるように なってきている，しかしながら，未だに多くの 治療中断者が存在することも事実であり, 自覚 症状のない糖尿病に対する治療継続のモチベー ションをいかに持続させ, また, 食事や運動・ 服薬等のセルフマネージメントをどのようにサ ポートするかが重要な問題となっている.これ に対すると対策として, IoT (internet of things)
機器を用いたセルフマネージメント支援や, PHR (personal health record) とEMR (electronic medical record)のシームレスな融合を実現させ ていく必要があると考えられる。一方, 我が国 の糖尿病患者の $30 \%$ 以上が後期高齢者であり， サルコペニアやフレイルの予防・改善を念頭に 置いた食事療法・運動療法や, 若年者に比べて 緩やかな管理目標の設定等がガイドラインでは 推奨されており,今後はその検証も重要である. いずれにせよ，患者の年齢や病態に応じた個別 化医療が可能となってきており, 大規模臨床試 験やレジストリの解析に基づいた非専門医にも 実践可能なEMRに組み込まれたリアルタイム診 療ガイダンスの開発も期待される.

\section{9. 腎代替療法選択と導入後管理}

\section{大阪大学大学院医学系研究科腎臟内科学 猪阪 善隆}

腎代替療法は, 血液透析 (hemodialysis：HD), 腹膜透析（peritoneal dialysis：PD）ならびに腎 移植が 3 本柱である。日本透析医学会統計調査 委員会の報告によると, 2017 年末の 33 万人を超 える透析患者のうち, HD患者が $97.3 \%$ を占め, PD患者の割合は減少傾向にある. 腎移植におい ても, 生体腎移植はやや増加傾向にあるものの, 献腎移植は 200 例程度であり, 1 万人を超える献 腎移植登録者に比べて極めて少ない. 我が国は, 諸外国と比較してPDや腎移植が少なく, 厚生労 働省も腎代替療法を必要とする患者のQOL (quality of life）の観点から，PDや腎移植を推進する 政策を打ち出している.

従来, 腎代替療法の選択にあたっては, パター ナリズムに基づく医師主導の意思決定がなされ ていたが, 時代と共にインフォームド・コンセン トという意思決定プロセスが用いられてきた. 近 年, 医療者と患者の双方がお互いの情報を共有し,
医学的な情報に加え, 患者の価值観やライフスタ イルの情報についても意見を出し合って意思決 定する shared decision making $(\mathrm{SDM})$ が提唱され ている.しかし, SDMのプロセスは容易ではない.

Standardized Outcomes in Nephrology （SONG）initiativeの報告によると，医療従事者 が重視するアウトカムが死亡や心血管病である のに対し, 患者が重視するのは旅行の可否や透 析をしていない自由時間である. 21 世紀医療の 中心概念の 1 つがpatient-centerednessであり， 治療の目的を「医学的な成績」ではなく,「患者 にとって価值のあるアウトカム」とする必要が ある、そのためには, SDMにより, 医療従事者 と患者のgapを埋める必要がある. 腎代替療法導 入後もまた同様である。このような患者参加型 医療により，患者の満足度が高まると共に，患 者の自己管理の向上や治療成績の向上, 不要な 入院の減少等が期待できる. 